\title{
Maize Development: Cell Wall Changes in Leaves and Sheaths
}

\author{
Ronald D. Hatfield*, Jane M. Marita \\ USDA-Agricultural Research Service, U.S. Dairy Forage Research Center, Madison, Wisconsin, USA \\ Email: *Ronald.Hatfield@ARS.USDA.Gov
}

How to cite this paper: Hatfield, R.D. and Marita, J.M. (2017) Maize Development: Cell Wall Changes in Leaves and Sheaths. American Journal of Plant Sciences, 8, 1248-1263.

https://doi.org/10.4236/ajps.2017.86083

Received: March 17, 2017

Accepted: May 19, 2017

Published: May 22, 2017

Copyright (ㅇ 2017 by authors and Scientific Research Publishing Inc. This work is licensed under the Creative Commons Attribution International License (CC BY 4.0).

http://creativecommons.org/licenses/by/4.0/

\begin{abstract}
Developmental changes occur in maize (Zea mays L.) as it transitions from juvenile stages to the mature plant. Changes also occur as newly formed cells mature into adult cells. Maize leaf blades including the midribs and sheaths undergo cell wall changes as cells transition to fully mature cell types. As is common in grasses during cell wall maturation, the lignin in the plant tissue is acylated with $p$-coumarates $(p C A)$. This work characterizes cell walls in maize that make up leaf blade, leaf midrib, and sheath tissues corresponding to tissue development. Maize plants grown in the greenhouse were harvested; leaf, leaf midrib, and sheath tissues from nodes 9 through 14 tissues were analyzed for cell wall composition. Cell wall carbohydrates varied with the type of maize tissue, but there was little change within a tissue type among the different nodes. Lignin concentrations were lowest in the leaf blade $\left(70-88 \mathrm{~g} \cdot \mathrm{kg}^{-1} \mathrm{CW}\right)$ followed by the sheath $\left(123-140 \mathrm{~g} \cdot \mathrm{kg}^{-1} \mathrm{CW}\right)$ and highest in the midrib (140 $168 \mathrm{~g} \cdot \mathrm{kg}^{-1} \mathrm{CW}$ ). Incorporation of $p \mathrm{CA}$ into cell walls paralleled the lignification. Ferulates (FA) remained relatively constant as a proportion of the cell wall (3.1 - $6.4 \mathrm{~g} \cdot \mathrm{kg}^{-1} \mathrm{CW}$ ) across nodes and across all tissue types. The range of FA was 3.8 vs $5.7 \mathrm{~g} \cdot \mathrm{kg}^{-1} \mathrm{CW}$ averaged over all nodes with leaf blades being the lowest. Lignin composition did not change significantly with cell wall maturation within a given tissue type. The aerial portions of maize plants excluding the stem showed little difference in cell wall composition along the different nodes. Higher levels of ferulates were found in the sheath and leaf midrib compared to the leaf blade tissues. Leaf midribs from the upper nodes of the plant contained the highest levels of lignin. Perhaps a reflection of the function to keep leaves extended and in an upward angle to help maximize photosynthetic capacity.
\end{abstract}

\section{Keywords}

Maize, Cell Walls, Lignin, Phenolics, Structural Carbohydrates 


\section{Introduction}

This Maize (Zea mays L.) is a prominent grain crop both in the United States and other countries throughout the world. In the dairy industry, it is an important nutritional biomass crop for milk production being preserved primarily as corn silage. With interest in biomass for energy production, there is potential for increased demand and competition in crop production between biomass for animal use and as a bioenergy source. No matter its final use it is important to maximize energy conversion efficiency from the crop to insure sufficient production is available to meet all food, fiber, and bioenergy needs. The fiber portion of plants is made of cell walls providing a structural framework to keep the plant upright and leaves extended to maximize photosynthetic capacity for continued growth and development and reproductive fitness. In grasses, like corn, accumulation of biomass occurs from the combined developmental processes of new cell formation, cell elongation, and cell wall thickening.

In maize development, leaves can be divided into groups based upon where they develop along the growing stem. Juvenile leaves are those that develop from seedling stage through internode 10 and have slightly different compositional characteristics compared to the adult leaves (above internode 10). Previous studies of cell wall composition in sequential leaves along the maize stem although limited, indicate variation exists. Bergvinson et al. [1] reported increased levels of cell wall-bound phenolic acids ( $p$-coumaric acid, $p$ CA and ferulic acid, FA) between leaves three and ten in the population BS9. Evans et al. [2], using a histological technique to measure relative amounts of lignin, concluded that epidermal cells in adult leaves of several maize inbreds have higher lignin levels than juvenile leaves of the same genotype. Cell wall composition of leaves and whole plant tissues vary with maturity in a number of forage grasses [3] [4]. Generally, tissues of smooth bromegrass (Bromus inermis Leyss.) and orchardgrass (Dactylis glomerata L.) harvested early in development have relatively higher molar fractions of arabinose, galactose, and uronosyls and lower fractions of cellulose, xylans, lignin, and bound phenolic monomers than tissues of plants harvested at later stages of development [5] [6]. Grabber and Jung [7] have shown individual sugars that make up polysaccharides in parenchyma and sclerenchyma cell types of grass cell walls can vary depending upon the grass species and the stage of development. Changes in the cell wall composition can also impact total digestibility [8].

Composition of cell walls can impact resistance to insect herbivory [9] [10] and ruminant digestibility [8] [11] in maize and other grass species. Generally, higher levels of lignin, and cross-linking of lignin through ferulates to cell wall carbohydrates, results in increased physical resistance to chewing and decreased availability of digestible components [12] [13]. Studies on changes in stem internodes from the oldest (lower) to the youngest (upper) internodes revealed compositional differences within the cell walls that make up the rind tissues of stem internodes [14]. The question of whether similar differences exist in lower node leaves and sheaths compared to the upper nodes were addressed in a com- 
positional study of developing maize plants. A thorough understanding of developmental changes in cell wall composition of sequential maize leaves should increase geneticists' abilities to develop cultivars with improved resistance to herbivory or increased digestibility. Our objective was to study cell wall composition in leaf blade, leaf midribs, and sheath tissues in maize plants that were at a tassel emergence stage to determine if differences exist within or among developmental nodes.

\section{Materials and Methods}

\subsection{Plant Materials}

Corn inbred B73 (obtained from Mycogen) was grown in greenhouses at the U.S. Dairy Forage Research Center, Madison, WI. Plants were established (two per pot) in late winter of 2009 in three gallon pots, watered as needed to maintain adequate soil moisture and fertilized once weekly (Pete's Soluble 10-10-10). Pots were labeled as one of three replicates and randomized within the greenhouse space. Four individual plants were harvested for each experimental replicate. Plants were cut through the seventh node (just above the soil line) with leaves and sheaths carefully removed from each stem. Nodes were labeled from 8 to the upper most internode that had undergone elongation (internode 14). Growing conditions can impact the leaf or internode number before plant development switches from a vegetative to a reproductive stage. Since all plants for this study were grown under controlled conditions in the greenhouse (14/10 day/night light regime, $26^{\circ} \mathrm{C}-28^{\circ} \mathrm{C}$ night $30^{\circ} \mathrm{C}-34^{\circ} \mathrm{C}$ day temperature), all plants developed relatively uniformly and leaves and sheaths were collected through node 14 and the tassel was removed for analysis. As leaves were removed from the stem the midrib of each was carefully excised from the leaf blade. Individual, leaf blades, sheaths, and midribs for each node were pooled across the four plants within an experimental replicate and processed, immediately frozen in liquid nitrogen and stored separately at $-80^{\circ} \mathrm{C}$.

\subsection{Preparation of Tissue Materials for Analysis}

The Frozen samples (sheaths, leaf blades, midribs) were further processed by grinding in a Freezer Mill (6750, Spex Sample Prep) using a pre-cool interval of 10 minutes followed by three cycles of two-minute grind (oscillation rate setting of 10)-one minute rest interval. After milling samples were immediately transferred to $50 \mathrm{~mL}$ centrifuge tubes in liquid nitrogen before storing at $-80^{\circ} \mathrm{C}$ until further processing.

A sub-sample of frozen ground tissue material (sheath, leaf blade or midrib) was accurately weighed into $50 \mathrm{~mL}$ Oakridge tubes $(5 \mathrm{~g})$. Thawed samples were extracted three times with $50 \mathrm{mM} \mathrm{NaCl}$ buffer $\left(2.5 \mathrm{~mL} \cdot \mathrm{g}^{-1}\right.$ sample). Samples were suspended in buffer, shaken $(175 \mathrm{rpm})$ at $40^{\circ} \mathrm{C}$ for $30 \mathrm{~min}$ before centrifuging at $2000 \times \mathrm{g}$ for $15 \mathrm{~min}\left(25^{\circ} \mathrm{C}\right)$ and the buffer extract carefully removed from the insoluble residue/pellet. The three buffer extracts were combined, frozen in liquid nitrogen and stored at $-80^{\circ} \mathrm{C}$ until processed for soluble phenolics. 
Tris-Acetate buffer (50 mM, pH 6.7) was then added to each insoluble residue, and samples were placed in a $90^{\circ} \mathrm{C}$ water bath for $2 \mathrm{~h}$. Samples were transferred to a $55^{\circ} \mathrm{C}$ water bath and incubated for $2 \mathrm{~h}$ after adding amylase (Sigma A3403 $10 \mathrm{U} /$ tube) and amyloglucosidase (Fluka $1011510 \mathrm{U} /$ tube) for starch removal. Ethyl alcohol (EtOH, 95\%) was added to each tube to make the final EtOH concentration $80 \%$. Samples were stirred with a spatula before centrifuging at 25000 $\times \mathrm{g}$ for $15 \mathrm{~min}$. Insoluble residues/pellets recovered from the starch extraction procedure were washed extensively ( $1 \mathrm{~mL}$ solvent/g fresh tissue). The solvent series included: $80 \% \mathrm{EtOH}(2 \mathrm{X})$, chloroform: methanol 2:1 $\left(\mathrm{CHCl}_{3}: \mathrm{MeOH} ; 1 \mathrm{X}\right)$, and acetone (3X) to remove cytoplasmic contaminants [15] [16]. Each wash included $30 \mathrm{~min}$ of shaking (in horizontal position) at $37^{\circ} \mathrm{C}$, centrifugation $(25,000$ $\times \mathrm{g}$ for $15 \mathrm{~min}$ ) and solvent removal. The final retained insoluble residues, mainly cell walls, were allowed to air dry under the hood and used for structural analysis.

\subsection{Structural Analysis of Leaf Blade, Sheath, Midrib}

Carbohydrate analyses. Cell wall residues were dried overnight in a $55^{\circ} \mathrm{C}$ oven prior to weighing for wall analysis. Samples $(\sim 50 \mathrm{mg})$ were accurately weighed into Pyrex culture tubes $(20 \times 125 \mathrm{~mm})$ with Teflon lined caps tubes. Four to five glass beads were added to each tube to aid in mixing during hydrolysis. Samples were hydrolyzed using the Saeman method [17] as modified by Hatfield. [16] [18] Briefly, dried samples were suspended in $1.5 \mathrm{~mL}$ of cold $\left(4^{\circ} \mathrm{C}\right) 12 \mathrm{M} \mathrm{H}_{2} \mathrm{SO}_{4}$, incubated at room temperature $\left(22^{\circ} \mathrm{C}-24^{\circ} \mathrm{C}\right)$ for $2 \mathrm{~h}$, and vortexed every $15-20$ min. At the completion of the first stage hydrolysis, the acid was diluted with $\mathrm{dH}_{2} \mathrm{O}(10 \mathrm{~mL})$. All samples were capped tightly and placed in a $100^{\circ} \mathrm{C}$ forced air oven for $3 \mathrm{~h}$. Samples were mixed twice during this secondary hydrolysis step by carefully inverting 2 - 3 times. After the secondary hydrolysis, samples were cooled in an ice water bath and $200 \mu \mathrm{L}$ removed from each for total uronosyls analysis. Inositol was added ( $15 \mathrm{mg}, 300 \mu \mathrm{L}$ of $50 \mathrm{mg} \cdot \mathrm{mL}^{-1}$ solution in water) as internal standard. Tubes were recapped and thoroughly mixed before a subsample $(0.75 \mathrm{~mL})$ was diluted to $15 \mathrm{~mL}$ with $\mathrm{dH}_{2} \mathrm{O}$ in a $50 \mathrm{~mL}$ centrifuge tube. Sub-samples were neutralized with barium carbonate, centrifuged $(3200 \times \mathrm{g} 15$ min) and the supernatant filtered through a glass fiber filter (0.2 micron, Acrodisc). Six $\mathrm{mL}$ of the filtered neutralized sub-samples were dried and sugars converted to alditol acetate derivatives using the procedure of Blakeney et al. [19] and analyzed by FID-GLC (Supelco SPB-225 column $30 \mathrm{~m} \times 0.25 \mathrm{~mm}$ with 0.25 micron film thickness). Samples removed for total uronosyls were diluted 10 fold with $\mathrm{dH}_{2} \mathrm{O}$ and analyzed using the method of Blumekrantz and AsboeHansen [20].

Lignin determination and analysis. Isolated cell walls were accurately weighed ( $25 \mathrm{mg} / \mathrm{sample}$ ) into glass culture tubes $(16 \mathrm{~mm} \times 150 \mathrm{~mm}$, with Teflon lined caps) for lignin determination. The acetyl bromide method was use as modified by Hatfield et al [21] [22]. Briefly acetyl bromide reagent $2.5 \mathrm{~mL}$ of $25 \%$ made up in glacial acetic acid was carefully added to each sample. Tubes were sealed and 
incubated for $2 \mathrm{~h}$ at $50^{\circ} \mathrm{C}$. After cooling the lignin-cell wall extracts were mixed and a subsample removed and centrifuged at $17000 \times \mathrm{g}$ for $5 \mathrm{~min}$ to clarify the reaction mixture. A $0.5 \mathrm{~mL}$ aliquot was removed from the supernatant and processed by adding to $9.5 \mathrm{~mL}$ of reagent $(2 \mathrm{~mL} 2 \mathrm{M} \mathrm{NaOH}, 0.35 \mathrm{~mL} 0.5 \mathrm{M}$ hydroxylamine, and $7.15 \mathrm{~mL}$ glacial acetic acid). Lignin extracts were scanned from 250 to $350 \mathrm{~nm}$ (Beckman DU-50). The extinction coefficient for calculating lignin concentration was based on a purified $\mathrm{HCl}$-dioxane lignin isolated from corn stems [23]. Lignin composition was determined using nitrobenzene oxidation following the procedure of Iiyama and Lam [24] with slight modifications. Briefly $4 \mathrm{~mL}$ of $2 \mathrm{M} \mathrm{NaOH}$ and $0.25 \mathrm{~mL}$ of nitrobenzene were added to accurately weighed $(\sim 20-25 \mathrm{mg})$ cell wall sample in stainless steel reaction vessels. Reaction vessels were sealed, placed in large glass beakers, and heated $\left(170^{\circ} \mathrm{C}\right)$ for $2 \mathrm{~h}$ in a forced air oven. At the completion of the heating cycle, reaction vessels were cooled under cold water. Individual reaction vessels were opened and contents quantitatively transferred to Pyrex culture tubes $(20 \times 250 \mathrm{~mm}$, with Teflon lined caps) with $\mathrm{dH}_{2} \mathrm{O}(2 \times 2 \mathrm{~mL})$. The reaction mixtures were extracted twice with chloroform $(4 \mathrm{~mL})$, followed by acidification with $12 \mathrm{M} \mathrm{HCl}(\mathrm{pH}<2)$, $100 \mu \mathrm{g}$ of 4, 4'-ethylidenebisphenol (EDB; Aldrich, $50 \mu \mathrm{l}$ of $2 \mathrm{mg} / \mathrm{mL}$ in $95 \%$ ethyl alcohol) added as internal standard, and extraction continued with ethyl ether $(5 \mathrm{~mL} 2 \mathrm{x})$ and dichloromethane $(5 \mathrm{~mL} 1 \mathrm{x})$. The ether and dicholormethane extracts were combined and half the sample volume was evaporated to dryness in reaction vials under filtered air. Nitrobenzene oxidation products were identified and quantified as trimethylsilane derivatives ( $40 \mu \mathrm{L}$ TMSI, Pierce and $10 \mu \mathrm{L}$ pyridine) using GLC-FID on a ZB-5ms column (Zebron; $30 \mathrm{~m} \cdot 0.25$ $\mathrm{mm}, 0.25$ micron film). The GLC conditions were injector $315^{\circ} \mathrm{C}$, detector $300^{\circ} \mathrm{C}$, and a temperature program of $150^{\circ} \mathrm{C}$ for $5 \mathrm{~min}, 4^{\circ} \mathrm{C} / \mathrm{min}$ to 200 , $10^{\circ} \mathrm{C} / \mathrm{min}$ to $240^{\circ} \mathrm{C}, 30^{\circ} \mathrm{C} / \mathrm{min}$ to $300^{\circ} \mathrm{C}$ and hold for $10 \mathrm{~min}$.

Cell wall phenolics. Cell walls were analyzed for ester- and ether-linked phenolics using the procedure of Grabber et al [25] [26] [27]. Briefly, samples were accurately weighed ( 100 mg) into Teflon vials ( $6 \mathrm{~mL}$ volume) fitted with Teflon caps. To each vial $2.5 \mathrm{~mL}$ of $2 \mathrm{M} \mathrm{NaOH}$ (degassed with $\mathrm{N}_{2}$ ) was added along with $100 \mu \mathrm{g}$ of 2-hydroxycinnamic acid ( $1 \mathrm{mg} \cdot \mathrm{mL}^{-1}$ in $\left.2 \mathrm{~N} \mathrm{NaOH}\right)$ and $100 \mu \mathrm{g}$ of synthetic 5 - 5 diferulate $\left(1 \mathrm{mg} \cdot \mathrm{mL}^{-1}\right.$ in $\left.2 \mathrm{~N} \mathrm{NaOH}\right)$. Tubes were gently swirled, flushed with nitrogen, capped and hydrolyzed overnight (for $20 \mathrm{~h}$ ) at room temperature. The $\mathrm{pH}$ was adjusted to 2 with $0.42 \mathrm{~mL} 12 \mathrm{M} \mathrm{HCl}$. Phenolic acids were extracted $3 \times$ into anhydrous ether and extracts combined and evaporated to dryness. Phenolics (monomers and dimers of ferulates) were identified and quantified as trimethylsilane derivatives $(40 \mu \mathrm{L}$ TMSI, Pierce and $10 \mu \mathrm{L}$ pyridine) using GLC-FID on a ZB-5ms column (Zebron; $30 \mathrm{~m} \times 0.25 \mathrm{~mm}, 0.25 \mathrm{mi}-$ cron film). The GLC conditions were injector $315^{\circ} \mathrm{C}, 300^{\circ} \mathrm{C}$ detector, and a temperature program of $220^{\circ} \mathrm{C}$ for $1 \mathrm{~min}, 4^{\circ} \mathrm{C} / \mathrm{min}$ to $248,30^{\circ} \mathrm{C} / \mathrm{min}$ to $300^{\circ} \mathrm{C}$ and hold for $20 \mathrm{~min}$.

To release ether linked phenolics the residual cell wall sample in the vials was allowed to stand in a hood overnight to evaporate small amounts of residual 
ether. To the cell wall suspensions $1.5 \mathrm{~mL}$ of $12 \mathrm{M} \mathrm{NaOH}$ was added along with $100 \mu \mathrm{g}$ of 2-hydroxycinnamic acid $\left(1 \mathrm{mg} \cdot \mathrm{mL}^{-1}\right.$ in $\left.2 \mathrm{~N} \mathrm{NaOH}\right)$ and $100 \mu \mathrm{g}$ of synthetic 5 - 5 diferulate $\left(1 \mathrm{mg} \cdot \mathrm{mL}^{-1}\right.$ in $\left.2 \mathrm{~N} \mathrm{NaOH}\right)$. Vials were sealed and placed inside a second larger reaction vessel (5 Telfon vials per large reaction vessel) along with a few $\mathrm{mL}$ of water. The reaction vessels were heated in a forced air oven $\left(170^{\circ} \mathrm{C}\right)$ for $2 \mathrm{~h}$. At the completion of the heating cycle, reaction vessels were cooled under cold water. Individual Teflon vials were opened and contents quantitatively transferred to Pyrex culture tubes $(20 \times 250 \mathrm{~mm}$, with Teflon lined caps) with $\mathrm{dH}_{2} \mathrm{O}(2 \times 1 \mathrm{~mL})$. Released phenolics were extracted and analyzed as with the ester-linked materials using GLC-FID under similar conditions.

\subsection{Statistical Analysis}

Data from individual experiments were subjected to analysis of variance (ANOVA) at the $\alpha=0.05$ significance level.

\section{Results and Discussion}

There are distinct changes in cell wall components as the corn plant matures. [14] [27] In the case of corn stem sections there is a developmental sequence that occurs within the stem internodes. Top portions of the internode are more mature and the bottom portions are made up of recently formed and expanded cells. In grasses, tissue expansion of plant parts such as leaves or stems occurs by an intercalary meristem at the tissue base, forming new cells that undergo rapid expansion to increase length. [28] The oldest cells are at the top of each stem internode and at the tip of each leaf. There is also a maturity trend within the whole stem of the corn plant with the bottom most internodes being mature (fully formed and expanded) while the upper most internodes may be fully formed in terms of new cell formation, but cells are not yet completely expanded and cell wall formation is not complete. These differences are primarily reflected in the shifts in cell wall neutral sugar composition indicating synthesis of secondary cell wall polysaccharides. This is usually identified as decreases in the amount of arabinose among the cell wall polysaccharides. For grasses, this is generally taken to indicate the incorporation of xylans with less arabinose substitution. There is an increase in lignin and $p C A$ as grass stem cell walls mature. The increase in $p \mathrm{CA}$ is closely tied to lignin since this is the major route of $p \mathrm{CA}$ incorporation into cell wall matrices. Ferulate levels in stem internodes tend to remain at a relatively constant proportion of the cell wall indicating that ferulate incorporation into the cell wall matrices continues throughout the development of both primary and secondary walls. As an overall comparison to the development of cell walls in this study, leaves, sheaths, and leaf midrib tissues did not demonstrate similar patterns of compositional shifts comparing the lower portions of the plant to the upper portions. Changes most often associated with maturation (e.g., increased lignin, increased cell wall content) [14] [27] were not more pronounced in the lower portions (internodes and nodes) of the maize plant when comparing, leaves, midribs, and sheaths. 
One would expect cell wall components (i.e., total neutral sugars, total uronosyls, total lignin and phenolics) to account for greater than $90 \%$ of the total dry matter isolated as corn cell wall. In this study, total neutral sugars and lignin account for nearly $90 \%$ of the total cell wall (Table 1) for sheath and midrib tissues. In the leaf blade tissue, total cell wall component recovery accounted for 60 to $70 \%$ of the isolated insoluble residue. The remaining material is most likely residual protein that was not completely removed from the original samples during cell wall isolation. Insoluble residue recoveries from the original tissue samples for the leaf blade are typically on the order of $60 \%-70 \%$.

Table 1 Summary of major cell wall components comprising leaf blade, leaf midrib, and sheath tissues of corn plants isolated from nodes 9 through 14 . Values are the means of three separate analyses of replicated pooled corn plants grown in the greenhouse.

Using fresh (frozen at $-80^{\circ} \mathrm{C}$ ) starting material helps in the cell wall clean up process to eliminate more of the cytosolic contaminates. Based on the cell wall analyses this would mean that of the original dry matter samples for leaf blade material was approximately 35\% - 40\% cell wall material and the remaining would be cell solubles made up of cytoplasmic materials. There was no consistent pattern of cell wall component changes within the leaf blade materials from the lowest node (most mature part of the plant) to the least mature the upper

Table 1. Total cell wall components.

\begin{tabular}{ccccccc}
\hline Tissue & $\begin{array}{c}\text { Corn } \\
\text { internode }\end{array}$ & $\begin{array}{c}\text { Neutral } \\
\text { Sugars }\end{array}$ & $\begin{array}{c}\text { Lignin } \\
\text { g.kg-1 }\end{array}$ & Uronosyls & Phenolics & $\begin{array}{c}\text { Total Cell } \\
\text { Wall }\end{array}$ \\
\hline Leaf & Node 9 & $441.8 \pm 39.3$ & $73.6 \pm 12.6$ & $27.4 \pm 0.5$ & $4.8 \pm 0.3$ & 547.6 \\
& Node 10 & $546.9 \pm 164.4$ & $87.3 \pm 6.5$ & $24.1 \pm 1.3$ & $5.6 \pm 0.8$ & 663.8 \\
& Node 11 & $487.3 \pm 23.0$ & $88.6 \pm 6.0$ & $21.6 \pm 3.8$ & $5.8 \pm 1.2$ & 603.2 \\
& Node 12 & $522.4 \pm 12.0$ & $91.5 \pm 9.2$ & $23.7 \pm 0.7$ & $7.2 \pm 0.8$ & 644.9 \\
& Node 13 & $521.6 \pm 58.3$ & $82.7 \pm 5.0$ & $23.9 \pm 1.0$ & $7.9 \pm 1.6$ & 636.0 \\
& Node 14 & $534.0 \pm 65.4$ & $87.5 \pm 13.1$ & $20.8 \pm 1.5$ & $8.0 \pm 0.7$ & 650.3 \\
Midrib & Node 9 & $824.6 \pm 60.3$ & $140.4 \pm 14.2$ & $32.5 \pm 2.4$ & $12.3 \pm 1.0$ & 1009.8 \\
& Node 10 & $597.4 \pm 49.1$ & $150.8 \pm 2.9$ & $29.5 \pm 2.8$ & $13.9 \pm 0.4$ & 791.6 \\
& Node 11 & $724.3 \pm 170.2$ & $146.9 \pm 30.0$ & $29.9 \pm 1.9$ & $15.1 \pm 0.5$ & 916.3 \\
& Node 12 & $774.1 \pm 62.2$ & $152.6 \pm 20.1$ & $26.6 \pm 3.4$ & $17.2 \pm 3.8$ & 970.4 \\
& Node 13 & $673.8 \pm 87.0$ & $170.1 \pm 10.3$ & $28.0 \pm 2.8$ & $15.3 \pm 0.2$ & 887.3 \\
& Node 14 & $740.1 \pm 104.7$ & $158.4 \pm 12.4$ & $27.9 \pm 1.9$ & $16.9 \pm 0.7$ & 943.3 \\
& Node 9 & $767.4 \pm 27.3$ & $140.3 \pm 8.7$ & $38.9 \pm 6.4$ & $12.4 \pm 1.5$ & 958.1 \\
& Node 10 & $734.2 \pm 20.7$ & $134.3 \pm 8.9$ & $35.0 \pm 6.8$ & $13.3 \pm 1.6$ & 916.8 \\
& Node 11 & $716.0 \pm 87.3$ & $127.2 \pm 21.8$ & $40.8 \pm 2.1$ & $14.8 \pm 2.3$ & 898.8 \\
& Node 12 & $708.2 \pm 44.1$ & $139.6 \pm 2.7$ & $39.4 \pm 2.6$ & $14.2 \pm 1.1$ & 895.4 \\
& Node 13 & $805.2 \pm 118.1$ & $136.4 \pm 30.5$ & $36.0 \pm 5.8$ & $14.6 \pm 1.9$ & 992.2 \\
& $835.0 \pm 47.5$ & $123.1 \pm 1.6$ & $36.3 \pm 2.1$ & $14.9 \pm 1.1$ & 1009.3 \\
\hline \multirow{2}{*}{ Nheath } & & & & &
\end{tabular}


most node (number 14). This may be expected because the function of the leaf blade tissue (largely mesophyll cells) is to carry out photosynthesis to supply metabolites for the rest of the growing plant. Since leaf development occurs from an intercalary meristem at the base of the leaf and the majority of the leaf used in this study examined fully expanded leaves one may not expect much of a change in cell wall composition. MacAdams and Grabber found grass leaf maturation occurred fairly rapidly once new cells were formed at the base of the leaf [29]. For the leaves used in this study there was no obvious difference in the proportions of cell wall components comparing the oldest leaves (lower nodes) to the most recently formed leaves (upper nodes). This was also true for the other two plant parts, sheaths and leaf midribs. There were no real differences in the proportion of individual wall components making up the cell wall when comparing older nodes to younger nodes, although there are differences in composition of the different tissue types. For the leaf midrib and sheath materials there is a shift to increased amounts of neutral sugars, lignin, and total phenolics as compared to the leaf blade tissue. However, once these tissues formed there is no additional development as typically indicated by increased lignification and phenolic incorporation into the wall matrix.

A detailed comparison of the individual chemical entities making up a given plant part (e.g., individual sugars within the total cell wall) does show minor shifts. A comparison of the three major sugars present in grass cell walls arabinose (Ara), xylose (Xyl), and glucose (Glc), which account for over $90 \%$ of the total neutral sugar composition, do show changes especially in the leaf blade tissues (Figure 1). When comparing sugars on a molar ratio basis, there is a trend for increased Xyl and decreased Ara. Based on ANOVA analysis Ara differences were significant at the $\mathrm{p}=0.05$ level across nodes of the corn plant. The slightly higher levels of Ara in the lower leaves (nodes 9 \& 10) compared to the upper leaves (nodes 11 to 14) may be a reflection of a transition from juvenile leaves to mature leaves [30]. This can be shown by plotting the Ara/Xyl ratio for the different tissues against the node they were harvested from (Figure 2). The leaf blade tissue clearly shows a decrease in this ratio in the upper node leaves. The leaf midrib tissue also shows a similar decline but it is of less magnitude. Sheath tissues showed no real changes in the Ara/Xyl ratio. These findings suggest there are minor changes in the neutral sugar composition of tissues isolated from nodes representing different stages of development of the maize plant. Due to the relatively small change in Ara and Xyl it is difficult to assign significant importance to them. It would indicate the incorporation of slightly less substituted arabinoxylans into the cell walls of younger leaves that are forming on the upper portions of the plant. However, it is not possible to interpret this in terms of changes in the structural function of these leaves. Glucose, the major cell wall sugar, did not appear to vary significantly within a given plant part comparing older to younger nodes (Figure 1). In fact, all plant parts in this study contained similar levels of glucose (approximately $50 \%$ of the total wall sugars). 


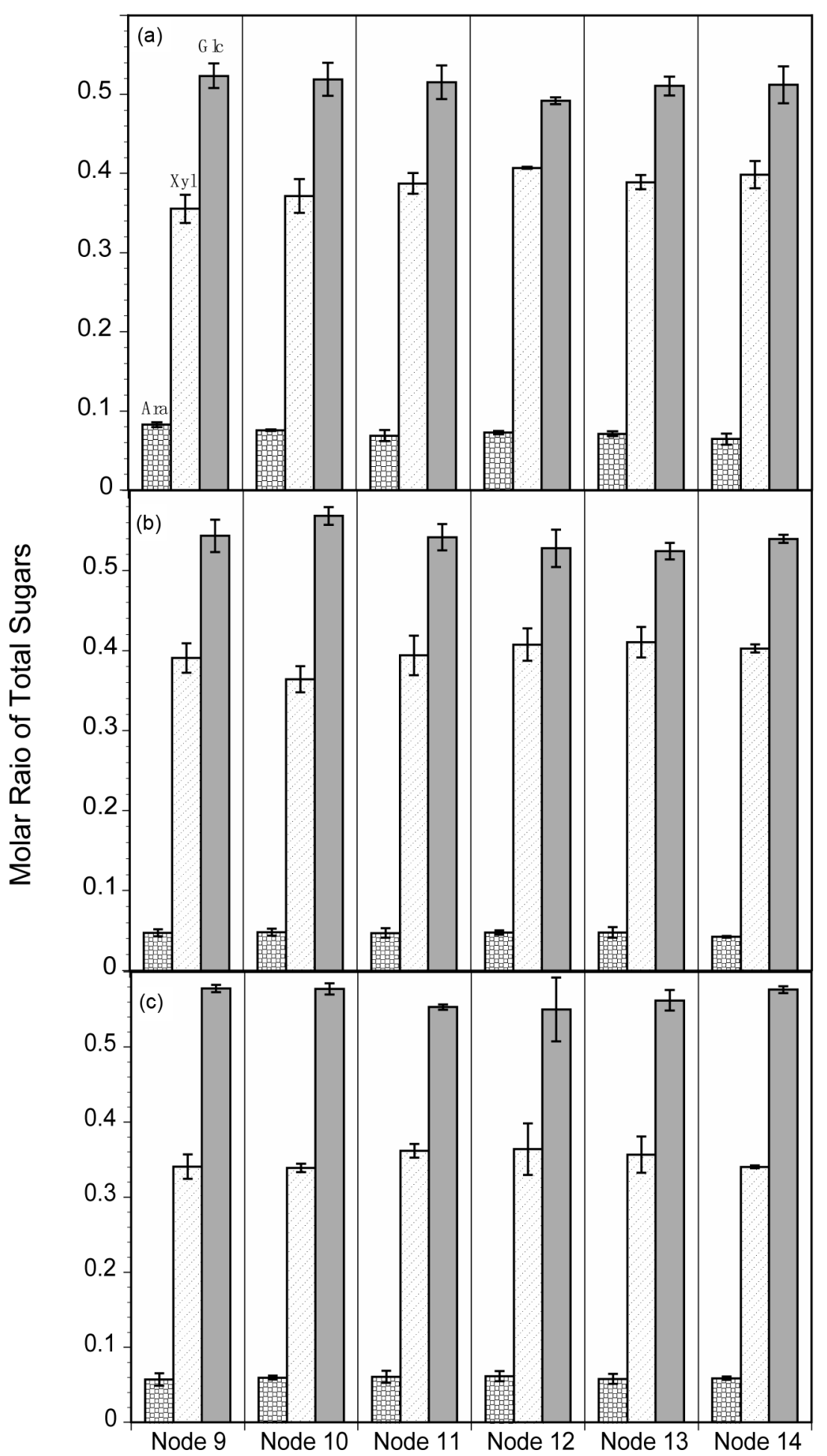

Figure 1. Comparison molar ratios of neural sugars recovered from total cell wall acid hydrolysis. Only arabinose (Ara), xylose (xyl), and glucose (Glc) are shown to simplify the graph. These sugars account for over $90 \%$ of the total neutral sugars found in the different tissues in this study. $\mathrm{A}=$ maize leaf, $\mathrm{B}=$ midrib, $\mathrm{C}=$ Sheath. ANOVA analysis was completed for all of the neutral sugars found in each plant part. There was no significant difference $(\mathrm{a}=0.05)$ for any of the sugars within a given plant part (leaf blade, midrib, or sheath) when comparing the lower nodes to the upper nodes of corn. Only Ara in the leaf blade showed a significant change from the lower nodes to the upper nodes. 


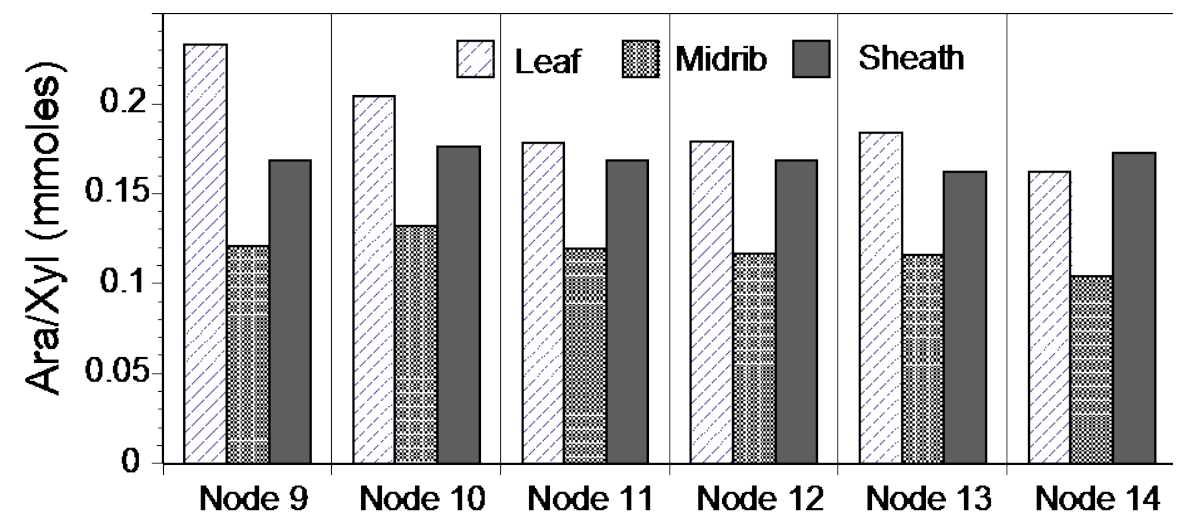

Figure 2. A comparison of the Ara: Xyl ratio for the different tissues analyzed for total neutral sugars. This ratio provides a means of assessing changes in synthesis patterns of hemicellulosic polysaccharides primarily arabinoxylans found in grasses.

Lignin accumulation within the leaf blade, leaf midrib, and sheath showed no consistent overall trends among the tissue types. The leaf blades tended to have levels that held steady at around $8 \%$ to $9 \%$ irrespective of the node the leaf came from (Table 1). Leaf midribs and sheaths contained higher levels of lignin with more variation within the different nodes. Sheath tissues displayed a slight shift to lower lignin levels in the upper nodes compared to the lower nodes. This is similar to developmental trends seen in corn internodes stem sections [14]. For midrib tissues there was an opposite trend with the upper nodes having higher lignin concentrations than the lower internodes (Table 1). The midrib of the leaf functions as a central support tissue and lignin is associated with increased structural strength of cell wall [31] [32]. It is possible the upper most leaves need additional strength to hold the leaf blade in a more horizontal position to ensure maximum capture of sunlight for photosynthesis. These leaves would certainly have the greatest potential for light interception since they are at the top of the canopy with minimal shading as compared to the lower leaves on the plant. Lignin composition, represented by the S/G ratio (Table 2), for the different types of tissues showed a trend for leaf blade tissues to contain higher syringyl type lignin in the lower nodes and this shifts to a higher guaiacyl type lignin in the upper nodes.

Although lignin subunits (syringyl vs guaiacyl) can change the amount of branching, it remains unclear as to the full impact of changing the proportion of $S$ to $G$ will have upon the overall functionality of the resulting lignin polymer. The leaf and midrib also show greater $S: G$ in the older tissue at the base of the stem which has been shown to occur in older tissue with more secondary wall formation.

Phenolic components in grass cell walls are primarily hydroxycinnamates ferulates $(\mathrm{FA})$ and $p$-coumarates $(p \mathrm{CA})$. Both are incororated into the wall matrix as ester linked conjugates. FA is primarily attached to Ara side chains of arabinoxylan (AX) and glucuronoarabinoxylans (GAX). In the case of FA they can undergo dehydrogenative radical coupling reactions to form a cross-linked network of ferulate dimers binding xylan polymers together. Due to the electro- 
Table 2. Comparison of lignin composition as syringyl to guaiacyl ratio (S/G) of corn leaf blade, leaf midrib, and sheath. Ratio is based upon the sum of oxidation products produced by nitrobenzene oxidation of individual samples. $S=$ syringylaldehyde + syringic acid + acetosyringone; $G$ = vanillin + vanillic acid + acetovanillone. $S: G$ ratio is the mean of duplicate assays on plant replicate samples (mean \pm std error).

\begin{tabular}{cccc}
\hline Internode & Leaf & Midrib & Sheath \\
& $\mathrm{S}: \mathrm{G}$ & $\mathrm{S}: \mathrm{G}$ & $\mathrm{S}: \mathrm{G}$ \\
\hline 9 & $2.21 \pm 0.02$ & $1.65 \pm 0.81$ & 5 \\
& 1 & 5 & $0.9 \pm 0.08$ \\
10 & $1.7 \pm 0.08$ & $1.1 \pm 0.04$ & 8 \\
& 7 & 5 & $0.7 \pm 0.02$ \\
11 & $1.2 \pm 0.02$ & $0.7 \pm 0.01$ & 6 \\
& 6 & 6 & $0.8 \pm 0.05$ \\
12 & $1.7 \pm 0.02$ & $1.0 \pm 0.08$ & 6 \\
& 9 & 4 & $0.5 \pm 0.01$ \\
13 & $0.7 \pm 0.40$ & $0.7 \pm 0.02$ & 8 \\
& 9 & 0 & $0.7 \pm 0.04$ \\
14 & $0.9 \pm 0.13$ & $0.8 \pm 0.09$ & 1 \\
& & & $0.9 \pm 0.06$ \\
\hline
\end{tabular}

chemical nature of FA radicals they can freely enter into radical mediated coupling reactions with radical species of guaiacyl and syringyl units on developing lignin polymers. This in turn produces a complex cross-linked wall matrix involving polysaccharides and lignin. In the case of $p \mathrm{CA}$ it can be incorporated into the cell wall matrix either as ester linked to Ara on AX or GAX polysaccharides or ester linked monolignols, primarily sinapyl alcohol. The $p \mathrm{CA}$ remains only attached by an ester linkage to the monolignol or Ara of the initial conjugate used to shuttle it out into the cell wall. Electrochemical properties of the pCA-monolignol conjugate (primarily $p C A-S A$ ) result in only the monolignol portion entering into radical mediated coupling reaction with other monolignols or FA. This results in $p C A$ remaining attached only by the original ester bond to lignin polymers. Typically $p \mathrm{CA}$ does not become involved in cross-coupling types of reactions to link different components together within the wall matrix. [14] A possible role for $p C A$ may be to aid in the formation of syringyl type lignins by acting as a radical shuttle mechanism between wall peroxidases and sinapyl alcohol components [33] [34].

Levels of $p$ CA tend to track with concentration of lignin within the different plant tissue types (Table 3). Midrib tissues have the highest lignin levels (140 $170 \mathrm{~g} \cdot \mathrm{kg}^{-1} \mathrm{CW}$ ) and these also contained the highest concentrations of esterified pCA ( 7.5 to $10.7 \mathrm{~g} \cdot \mathrm{kg}^{-1} \mathrm{CW}$ ). Sheath tissues contained the next highest levels of lignin (123-140 g. $\left.\mathrm{kg}^{-1} \mathrm{CW}\right)$ and had the second highest levels of esterified $p C A$ (6.7 to $9.1 \mathrm{~g} \cdot \mathrm{kg}^{-1} \mathrm{CW}$ ). There is not a direct correlation between $p \mathrm{CA}$ and lignin levels, but there is a trend for tissues with higher lignin to also have higher levels of esterified $p C A$. In leaves, the lignin levels were approximately half the lignin level in the other tissues, however the amount of esterified $p C A$ in the leaf blade was only about one third the level found in the other more heavily lignified tissues. As expected little ether linked $p C A$ is detected in any of the tissues examined (Table 3). 
Table 3. Summary of ester and ether linked p-coumarates ( $p C A)$ and ferulates (FA) extracted from the cell walls of leaf blade, leaf midrib, and sheath tissues from corn nodes 9 through 14. Concentrations of individual components are the mean of three plant replicates and duplicate analysis of cell walls isolated from each tissue with standard error listed as \pm of mean value.

\begin{tabular}{|c|c|c|c|c|c|}
\hline & & Ester Linked & & Ether linked & \\
\hline & & $p \mathrm{CA}$ & FA & $p \mathrm{CA}$ & FA \\
\hline Tissue & Node & $\mathrm{g} \cdot \mathrm{kg}^{-1} \mathrm{CW}$ & $\mathrm{g} \cdot \mathrm{kg}^{-1} \mathrm{CW}$ & $\mathrm{g} \cdot \mathrm{kg}^{-1} \mathrm{CW}$ & $\mathrm{g} \cdot \mathrm{kg}^{-1} \mathrm{CW}$ \\
\hline \multirow[t]{6}{*}{ Leaf } & 9 & $1.70 \pm 0.11$ & $2.93 \pm 0.18$ & $0.03 \pm 0.01$ & $0.13 \pm 0.01$ \\
\hline & 10 & $2.06 \pm 0.34$ & $3.39 \pm 0.46$ & $0.03 \pm 0.01$ & $0.14 \pm 0.03$ \\
\hline & 11 & $2.19 \pm 0.34$ & $3.41 \pm 0.84$ & $0.03 \pm 0.01$ & $0.15 \pm 0.01$ \\
\hline & 12 & $2.75 \pm 0.22$ & $4.28 \pm 0.49$ & $0.04 \pm 0.01$ & $0.17 \pm 0.03$ \\
\hline & 13 & $3.18 \pm 0.70$ & $4.50 \pm 0.86$ & $0.04 \pm 0.01$ & $0.15 \pm 0.01$ \\
\hline & 14 & $3.28 \pm 0.32$ & $4.50 \pm 0.32$ & $0.04 \pm 0.01$ & $0.16 \pm 0.01$ \\
\hline \multirow[t]{6}{*}{ Midrib } & 9 & $7.48 \pm 0.71$ & $4.56 \pm 0.22$ & $0.06 \pm 0.01$ & $0.24 \pm 0.04$ \\
\hline & 10 & $8.38 \pm 0.19$ & $5.17 \pm 0.17$ & $0.07 \pm 0.00$ & $0.27 \pm 0.02$ \\
\hline & 11 & $9.26 \pm 0.17$ & $5.43 \pm 0.24$ & $0.08 \pm 0.03$ & $0.31 \pm 0.08$ \\
\hline & 12 & $10.78 \pm 2.10$ & $5.86 \pm 1.55$ & $0.10 \pm 0.01$ & $0.42 \pm 0.06$ \\
\hline & 13 & $9.69 \pm 0.07$ & $5.25 \pm 0.11$ & $0.09 \pm 0.02$ & $0.31 \pm 0.04$ \\
\hline & 14 & $10.67 \pm 0.22$ & $5.86 \pm 0.40$ & $0.07 \pm 0.01$ & $0.31 \pm 0.04$ \\
\hline \multirow[t]{6}{*}{ Sheath } & 9 & $6.74 \pm 1.23$ & $5.40 \pm 0.23$ & $0.05 \pm 0.01$ & $0.17 \pm 0.03$ \\
\hline & 10 & $7.23 \pm 0.87$ & $5.76 \pm 0.64$ & $0.06 \pm 0.01$ & $0.23 \pm 0.05$ \\
\hline & 11 & $8.31 \pm 0.70$ & $6.12 \pm 1.53$ & $0.06 \pm 0.02$ & $0.25 \pm 0.08$ \\
\hline & 12 & $8.20 \pm 0.32$ & $5.68 \pm 0.76$ & $0.06 \pm 0.00$ & $0.25 \pm 0.01$ \\
\hline & 13 & $8.30 \pm 1.32$ & $5.93 \pm 0.48$ & $0.09 \pm 0.01$ & $0.30 \pm 0.06$ \\
\hline & 14 & $9.13 \pm 0.17$ & $5.37 \pm 0.89$ & $0.09 \pm 0.02$ & $0.31 \pm 0.05$ \\
\hline
\end{tabular}

Ferulates on the other hand have less variation among the different tissue types. Leaf blade tissue ranged from 3 to $4.5 \mathrm{~g} \cdot \mathrm{kg}^{-1} \mathrm{CW}$, midrib 4.6 to $5.9 \mathrm{~g} \cdot \mathrm{kg}^{-1}$ $\mathrm{CW}$, and sheath 5.4 to $6.1 \mathrm{~g} \cdot \mathrm{kg}^{-1} \mathrm{CW}$ (Table 3). Similar patterns were seen for the ether linked ferulates, but at a much lower concentration overall ( 0.13 to 0.41 $\mathrm{g} \cdot \mathrm{kg}^{-1} \mathrm{CW}$ across all tissues). Although the procedures used in this study are adequate for indicating the levels of ether linked FA it should not be assumed that this represents the total amount of FA bound to lignin within these maize tissues. There are other types of linkages that FA could form when coupling with monolignols to produce cross-links between GAX and lignin [35]. The amount of etherified FA increased in midrib and sheath tissues in conjunction with higher lignin values in these tissues. There is a trend to higher levels of etherified FA in the midrib and sheath tissues in upper nodes as compared to the lower nodes unlike the ester linked FA, therefore it is difficult to assign a functional role to this observation. Coupling of FA to lignin is dependent upon the amount of FA and monolignols that are in any given region of a cell wall matrix at the 
time of lignification. It has been proposed that FA may act as nucleation sites for lignin formation [35]. If this is the case FA may help direct lignification to occur in key areas of the cell wall matrix initially to optimize lignin's properties and function of the wall. We do not know the ultra-structural distribution of FA within the matrix, but it seems likely that FAs are incorporated into the wall as clusters in order to ensure cross-liking to form FA dimers. This could be accomplished by the formation of highly substituted regions of feruoylated arabinosyl residues on arabinoxylans during polysaccharide biosynthesis before incorporation into the wall. This would also help direct lignification to be initiated in key areas of the cell wall matrix [36]. It is clear that altering the amount of crosslinking within the wall matrix does impact the function of cell walls especially in terms of digestibility [13].

\section{Conclusion}

A comparison of leaf blade, leaf midrib, and sheath tissues of the corn plant revealed different chemical compositions within the tissue types. However, within a given tissue type there were no obvious large changes in this chemical make-up from the bottom older nodes to the top younger nodes. The leaf blade, leaf midrib and sheath tissues along the stem do not reflect the changes seen in the "actively growing" (elongation and expansion) of the stem internodes [14]. The near equal levels of Glc across the nodes suggest that leaves are not still actively growing and that leaf maturation is reached earlier than stem internode tissues. In terms of nutrient availability to ruminants, this would seem to represent a relatively uniform nutrient source for the animal especially since leaf blades make up the bulk of total material among these tissues. Once the leaf is fully expanded little additional change occurs as the plant continues to develop and age. This should provide a consistent nutrient supply to animals or as biomass for conversion to liquid fuels.

\section{References}

[1] Bergvinson, D.J., Hamilton, R.I. and Arnason, J.T. (1995) Leaf Profile of Maize Resistance Factors to European Corn-Borer, Ostrinia-Nubilalis. Journal of Chemical Ecology, 21, 343-354. https://doi.org/10.1007/BF02036722

[2] Evans, M.M.S., Passas, H.J. and Poethig, R.S. (1994) Heterochronic Effects of Glossy15 Mutations on Epidermal-Cell Identity in Maize. Development, 120, 1971-1981.

[3] Burritt, E.A., et al. (1985) Comparison of Laboratory Methods for the Prediction of in Vitro Dry Matter Digestibility in Three Maturing Grasses. Journal of Agricultural and Food Chemistry, 33, 725-728 https://doi.org/10.1021/jf00064a040

[4] Morrison, I.M. (1980) Changes in the Lignin and Hemicellulose Concentrations of Ten Varieties of Temperate Grasses with Increasing Maturity. Grass and Forage Science, 35, 287-293. https://doi.org/10.1111/j.1365-2494.1980.tb01525.x

[5] Buxton, D.R., Russell, J.R. and Wedin, W.F. (1987) Structural Neutral Sugars in Legume and Grass Stems in Relation to Digestibility. Crop Science, 27, 1279-1285. https://doi.org/10.2135/cropsci1987.0011183X002700060038x

[6] Buxton, D.R. and Russell, J.R. (1988) Lignin Constituents and Cell-Wall Digestibili- 
ty of Grass and Legume Stems. Crop Science, 28, 553-558. https://doi.org/10.2135/cropsci1988.0011183X002800030026x

[7] Grabber, J.H. and Jung, G.A. (1991) Isolation of Parenchyma and Sclerenchyma Cell Types from the Plant Parts of Grasses. Crop Science, 31, 838-842. https://doi.org/10.2135/cropsci1991.0011183X003100030058x

[8] Grabber, J.H., et al. (1992) Digestion Kinetics of Parenchyma and Sclerenchyma Cell Walls Isolated from Orchardgrass and Switchgrass. Crop Science, 32, 806-810. https://doi.org/10.2135/cropsci1992.0011183X003200030046x

[9] Coors, J.G. (1987) Resistance to the European Corn Borer, Ostrinia nubilalis (Hubner), in Maize, Zea mays L., as Effected by Soil Silica, Structural Carbohydrates, and Lignin. In: Genetic Aspects of Plant Mineral Nutrition, Martinus Nijhoff, Dordrecht, 445-456. https://doi.org/10.1007/978-94-009-3581-5_43

[10] Bergvinson, D.J., et al. (1994) Putative Role of Photodimerized Phenolic-Acids in Maize Resistance to Ostrinia-Nubilalis (Lepidoptera, Pyralidae). Environmental Entomology, 23, 1516-1523. https://doi.org/10.1093/ee/23.6.1516

[11] Hartley, R.D. and Ford, C.W. (1989) Phenolic Constituents in Plant Cell Walls and Wall Biodegradability. In: Lewis, N.G. and Paice, M.G., Eds., Plant Cell Wall Polymers, Biogenesis and Biodegradation, American Chemical Society, Washington DC, 137-145. https://doi.org/10.1021/bk-1989-0399.ch009

[12] Grabber, J.H., Hatfield, R.D. and Ralph, J. (1998) Diferulate Cross-Links Impede the Enzymatic Degradation of Nonlignified Maize Walls. Journal of the Science of Food and Agriculture, 77, 193-200. https://doi.org/10.1002/(SICI)1097-0010(199806)77:2<193::AID-JSFA25>3.0.CO;2$\underline{\mathrm{A}}$

[13] Grabber, J.H., Ralph, J. and Hatfield, R.D. (1998) Ferulate Cross-Links Limit the Enzymatic Degradation of Synthetically Lignified Primary Walls of Maize. Journal of Agricultural and Food Chemistry, 46, 2609-2614. https://doi.org/10.1021/jf9800099

[14] Hatfield, R.D., Marita, J.M. and Frost, K. (2008) Characterization of p-Coumarate Accumulation, p-Coumaroyl Transferase, and Cell Wall Changes during the Development of Corn Stems. Journal of the Science of Food and Agriculture, 88, 25292537. https://doi.org/10.1002/jsfa.3376

[15] Hatfield, R.D. (1992) Carbohydrate Composition of Alfalfa Cell Walls Isolated from Stem Sections Differing Maturity. Journal of Agricultural and Food Chemistry, 40, 424-430. https://doi.org/10.1021/jf00015a012

[16] Hatfield, R.D., Wilson, J.R. and Mertens, D.R. (1999) Composition of Cell Walls Isolated from Cell Types of Grain Sorghum Stems. Journal of the Science of Food and Agriculture, 79, 891-899.

https://doi.org/10.1002/(SICI)1097-0010(19990501)79:6<891::AID-JSFA304>3.0.CO ;2-\#

[17] Saeman, J.F., Moore, W.E. and Millett, M.A. (1963) Sugar Units Present. In: Cellulose, W.R.L., Ed., Hydrolysis and Quantitative Paper Chromatography, Academic Press, New York, 54-69.

[18] Hatfield, R.D., et al. (1994) A Comparison of the Insoluble Residues Produced by the Klason Lignin and Acid Detergent Lignin Procedures. Journal of the Science of Food and Agriculture, 65, 51-58. https://doi.org/10.1002/jsfa.2740650109

[19] Blakeney, A.B., et al. (1983) A Simple and Rapid Preparation of Alditol Acetates for Monosaccharide Analysis. Carbohydrate Research, 113, 291-299.

[20] Blumenkrantz, N. and Asboe-Hansen, G. (1973) New Method for Quantitative De- 
termination of Uronic Acids. Analytical Biochemistry, 54, 484-489.

[21] Hatfield, R.D., et al. (1999) Using the Acetyl Bromide Assay to Determine Lignin Concentrations in Herbaceous Plants: Some Cautionary Notes. Journal of Agricultural and Food Chemistry, 47, 628-632. https://doi.org/10.1021/jf9808776

[22] Fukushima, R.S. and Hatfield, R. (2004) Comparison of the Acetyl Bromide Spectrophotometeric Method with Other Analytical Lignin Methods for Determining Lignin Concentration in Forage Samples. Journal of Agricultural and Food Chemistry, 52, 3713-3720. https://doi.org/10.1021/jf0354971

[23] Fukushima, R.S. and Hatfield, R.D. (2001) Extraction and Isolation of Lignin for Utilization as a Standard to Determine Lignin Concentration Using the Acetyl Bromide Spectrophotometric Method. Journal of Agricultural and Food Chemistry, 49, 3133-3139. https://doi.org/10.1021/jf010449r

[24] Iiyama, K. and Lam, T.B.T. (1990) Lignin in Wheat Internodes. Part 1: The Reactivities of Lignin Units during Alkaline Nitrobenzene Oxidation. Journal of the Science of Food and Agriculture, 51, 481-491. https://doi.org/10.1002/jsfa.2740510405

[25] Grabber, J.H., et al. (1995) Ferulate Cross-Linking in Cell Walls Isolated from Maize Cell Suspensions. Phytochemistry, 40, 1077-1082.

[26] Grabber, J.H., et al. (1996) Dehydrogenation Polymer-Cell Wall Complexes as a Model for Lignified Grass Walls. Journal of Agricultural and Food Chemistry, 44, 1453-1459. https://doi.org/10.1021/jf9502717

[27] Morrison, T.A., et al. (1998) Cell-Wall Composition of Maize Internodes of Varying Maturity. Crop Science, 38, 455-460. https://doi.org/10.2135/cropsci1998.0011183X003800020031x

[28] Katherine, E. (1977) Anatomy of Seed Plants. 2nd Edition, John Wiley \& Sons, Inc., Hoboken.

[29] MacAdam, J.W. and Grabber, J.H. (2002) Relationship of Growth Cessation with the Formation of Diferulate Cross-Links and p-Coumaroylated Lignins in Tall Fescue Leaf Blades. Planta, 215, 785-793. https://doi.org/10.1007/s00425-002-0812-7

[30] Abedon, B., Hatfield, R.D. and Tracy, W. (2006) Cell Wall Composition in Juvenile and Adult Leaves of Maize (Zea mays L.). Journal of Agriculture and Food Chemistry, 54, 3896-3900. https://doi.org/10.1021/jf052872w

[31] Ralph, J., et al. (2004) Lignins: Natural Polymers from Oxidative Coupling of 4-Hydroxyphenylpropanoids. Phytochemistry Reviews, 3, 29-60. https://doi.org/10.1023/B:PHYT.0000047809.65444.a4

[32] Ralph, J., et al. (2007) Lignification: Are Lignins Biosynthesized via Simple Combinatorial Chemistry or via Proteinaceous Control and Template Replication? In: Daayf, F., et al., Eds., Advances in Polyphenols Research, Blackwell Publishing, Oxford, Vol. 1, 37-66.

[33] Hatfield, R., Ralph, J. and Grabber, J.H. (2008) A Potential Role for Sinapyl p-Coumarate as a Radical Transfer Mechanism in Grass Lignin Formation. Planta, 228, 919-928. https://doi.org/10.1007/s00425-008-0791-4

[34] Takahama, U. and Oniki, T. (1997) Enhancement of Peroxidase-Dependent Oxidation of Sinapyl Alcohol by an Apoplastic Component, 4-Coumaric Acid Ester Isolated from Epicotyls of Vigna angularis L. Plant and Cell Physiology, 38, 456-462. https://doi.org/10.1093/oxfordjournals.pcp.a029189

[35] Ralph, J., Grabber, J.H. and Hatfield, R.D. (1995) Lignin-Ferulate Crosslinks in Grasses: Active Incorporation of Ferulate Polysaccharide Esters into Ryegrass Lignins. Carbohydrate Research, 275, 167-178.

[36] Hatfield, R.D., Rancour, D.M. and Marita, J.M. (2017) Grass Cell Walls: A Story of 
Cross-Linking. Frontiers in Plant Science, 7, 2056.

https://doi.org/10.3389/fpls.2016.02056

Submit or recommend next manuscript to SCIRP and we will provide best service for you:

Accepting pre-submission inquiries through Email, Facebook, LinkedIn, Twitter, etc. A wide selection of journals (inclusive of 9 subjects, more than 200 journals)

Providing 24-hour high-quality service

User-friendly online submission system

Fair and swift peer-review system

Efficient typesetting and proofreading procedure

Display of the result of downloads and visits, as well as the number of cited articles Maximum dissemination of your research work

Submit your manuscript at: http://papersubmission.scirp.org/

Or contact ajps@scirp.org 